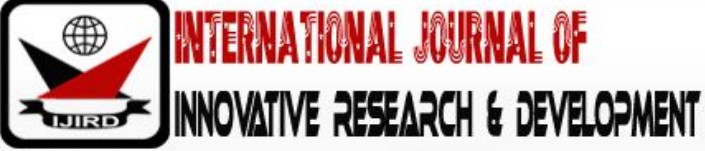

ISSN 2278 - 0211 (Online)

\section{A Review of the Concept of School-Based Leadership and Underlying Theories of Organizational Management}

\author{
Nomah Emmanuel \\ Tutor, Department of Social Sciences, Dambai College of Education, Ghana \\ Buah Emmanuel \\ Circuit Spervisor, Department of Ghana Education Service, \\ Techiman North District Education Directriate, Ghana
}

\begin{abstract}
:
This paper reviewed conceptions of school-based leadership and the theories of organizational management that underpin the various conceptions, and came out with an operational definition to enhance more understanding of the concept. From the review, it was emerged that there are two main schools of thought of the conception of school-based leadership. These conceptions are; the traditional concept and modern concept. The traditional conception is underpinned by the classical theory of organizational management, while the modern conception is underpinned by the human relation theory of organizational management. This paper recommends heads of schools to seek a broader understanding of the concept school-based leadership that reflects both the traditional and modern conceptions to enable them to have effective leadership for the various schools.
\end{abstract}

Keywords: School-based, leadership, traditional, modern, conception, organizational, management, theories

\section{Background to the Study}

The concept leadership has attracted a significant attention in recent years, though it has been an issue of concern to many scholars in different fields of study several years ago (Rothwell, 2000). Leadership is about the process or processes of realizing institutional goals via effective and efficient usage of human, material as well as information resources (Van Fleet \& Peterson, 1988). According to Danchi (2014), leadership refers to the capacity to influence and/ or direct the behaviour of subordinates in line with the aspirations of a group, towards the feasibility of the goals of an institution. The leader thus becomes the official mouthpiece of the group and the group as well recognizes him or her as such.

A cursory look at the leadership of an institution is closely linked to the study of the institution's efficiency and effectiveness (Schermerhorn, Hunt \& Osborn, 2000). The words of a leader in line with the operations of the institution or the group he/ she represents represent the voice of the group. Therefore, the success or the failure of the leader with regard to the running of an institution is a replica of the success or failure of the group. Leadership ensures that resources put into use yields maximum output to arrive at efficiency(Oduro \& Bakah as cited in Amakyi, Ampah-Mensah, Bosu, \& Dare. 2015). Therefore, leadership ensures that the work environment is conducive or attractive for workers to become effective.

Danchi (2014) acknowledged that in a school setting, the essence of leadership is real in sectors like; the school climate, use of instructional time and practice, academic performance and students discipline among others. Danchi further contended that leadership is critical in establishing a school that value and constantly endeavour to realize excellence in education for students/pupils. Similarly, in the school, the effective leadership of the head can preponderantly enhance school climate which can affect positively students' academic performance (Marzano \& McNaulty, as cited in Danchi, 2014). In the opinion of Danchi (2014), this implies that the ultimate task of the leader of a school is to create conducive atmosphere that encourages hard work towards effective teaching and learning. A leader's effectiveness is a function of his/ her absolute conception of the role he/ she plays as a leader in line with the vision and mission to be accomplished. The understanding of leadership role(s) of a leader no doubt would provide a clear-cut channel for him or her to direct resources available effectively, towards realizing the group's objectives, thereby minimizing waste.

Being a controversial issue with regard to a universally accepted definition or explanation for it, numerous individuals and organizations have attempted varied definitions and/ or explanation for the concept leadership, often to suit their vision and mission for pursuing leadership role. In spite of the varied definitions, built in many conceptions of the concept leadership, is about the fact that leadership concerns an influence or directive process that is geared towards facilitating and enhancing the performance of a collective task (Oduro \& Bakah as cited in Amakyi, Ampah-Mensah, Bosu, \& Dare, 2015). The different or divergent goals leaders often pursue in the course of their leadership career provide basis, for the perceived different conceptions they may hold for the concept. Even though leadership effectiveness is as a result of 
numerous factors, a leader's concise conception of his/ her leadership task in relation with the goals to be achieved, no doubt would go a long way to give a leader focus for effective leadership.

Effective leadership in school administration is a prerequisite for the realization of the educational goals a school is established to accomplish. This then calls for a concise and broader understanding of the concept school-based leadership by heads of schools

\subsection{Purpose of the Study}

The purpose of this study was to review conceptions on the concept school-based leadership put the reviewed conceptions into schools of taught and identify the theories of organizational management that underpin the schools of taught.

\subsection{Conceptualizations of School-Based Leadership}

A review of the literature emerged significant issues related to objective one of the studies. It emerged that there exist two major schools of taught, when it understands of the concept school-based leadership. The two conceptions are the traditional and modern conceptions of school-based leadership. The traditional conception of school-based leadership is characterized by strict adherence to bureaucratic and hierarchical structures, exercise of power by heads on staff members, with little or no room for initiative by subordinates in getting work done (Simonton, 1994; Ford and Hamilton, 1998; Caldwell, 2000; Sinha and Parvinder, 2002; Popvici, 2012 and Northouse, 2016). While the modern conception is also embedded with the principles of motivation, room for initiative and participatory decision-making among others. It as well emphasizes mutual respect and concern for staff members and recognizes them as integral part in the running of educational institution (Conley, 1991; Maxwell, 1999; Jones and George, 2000; Schermerhorn, Hunt and Osborn, 2000; Sinha and Parvinder, 2002; Tandoh, 2011 and Oduro and Bakah as cited in Amakyi et al., 2015).

In line with objective one of the studies, relevant literature regarding conceptualization of the concept schoolbased leadership espouses two schools of taught, which could be captioned as the traditional and the modern conceptions of school-based leadership. Anderson, Ford and Hamilton (1998) have observed that the traditional conception of schoolbased leadership is bureaucratically and/ or hierarchically oriented, based on heads issuing orders for staff to obey or follow. In other words, the school head exercises power over the followers to obtain their cooperation and commitment. Northouse (2016) collaborated with this view by understanding school-based leadership as a process whereby an individual (school head) influences a group of individuals (staff members) to achieve the common goal of an educational institution without recourse to the inputs of staff members in the decision-making process. Leadership in this sense is seen as the capacity to exercise power over others, the ability to direct (Popovici, 2012) followers to achieve a desired goal. This conception of leadership in educational institutions follows strict adherence to hierarchy and emphasis greatly on task, focusing on heads role of making decisions and ensuring their accomplishment through instructions to and feedback from staff members.

According to Sinha and Parvinder (2002), this conception of educational leadership has little or no consideration for rationale persuasion. That is reasoning with subordinates or staff members to impress upon them to appreciate the rationale, for why they must perform well without which the institution will not be able to realize its' objectives and goals, but rather upholds pressure on staff members by the head. Meaning direct demand, often amounting to coercive directives on staff members to do what they are hired to do. There is no room for reasoning or personal initiative, appeal, promise or reward, or persuasion for getting compliance. In contributing to this conception of school-based leadership, Oduro and Bakah (as cited inAmakyi et al., 2015) contended that this conception of school-based leadership is bureaucratic or hierarchical in nature, built in it, is a policy-making level such as the Ministry of Education, or participatory divisions (in the case of the GES, Ghana), which occasionally uses feedback from teachers and other educational workers within the system to develop standards and structures. In the same vein, Caldwell (2000) noted that school-based leadership is an organized transfer of power from a center to the school level which empowers the school head to exercise authority and responsibility regarding decision-making on issues that borders on the running of the school within the domain of framework defined by the center with respect to goals, policies, curriculum, standards, transparency, and accountability. This implies that the school head exercise control over his/ her followers base on a structured and systematic framework from the center, while the center also depends on the unit head (school head) for feedback base on strict adherence to dictates within the provided framework for reforms. Simonton (1994) contributed to this conception, by defining schoolbased leadership as the ability of school heads to compel, and influence staff members to contribute towards the achievement of the goals of the institution of which they are members.

The modern conception espouses the conviction that there must be less stress on strict compliance or absolute reliance on bureaucracy and hierarchical orders in the management of educational resources at the school level. Meaning school-based leadership should be minimal on the observance of bureaucratic principles and hierarchical structures, where the head of a school order staff members, and make decision for them to implement base on pre-determined framework provided by the center, to one that require heads to emphasize motivation, personal initiatives, inclusion and empowerment of staff members (Tandor, 2011) in the running of educational institutions. In line with this conception of managing educational institutions, Jones and George (2000) defined school-based leadership as a process in which heads of schools set direction for staff members and carries them along in that direction with competence and motivation. This school of thought emphasizes on leadership that brings positive change to the institution and its staff members as well, and improves the interpersonal relationship of staff members and the work environment.

Oduro and Bakah (as cited inAmakyi et al., 2015) supported this thinking when they explained that: 
School based-leadership is a relatively new style, that focuses less on bureaucratic policy of development and more on giving educators (individuals and groups), professional responsibility which can be used for anything from curriculum development to discipline methods (p.19).

This conception of school-based leadership is mainly about a shared responsibility and strategies that make individuals and groups of the school community to feel and realize that they are integral part of the equation meant for the realization of the vision and mission of the school as an institution. Similarly, based on this conception, Conley (1991) observed that school-based leadership is a tool for enhancing teacher participation and a means of ensuring collective responsibility in the running of the school as a unit. Also, in line with this conception, Maxwell (1999) explained school-based leadership as the capacity of the school head to listen, observe, and to use his/ her expertise to promote dialogue between all levels of decision-making, to establish processes and transparency in decision-making, and to articulate his/ her own values and visions clearly but not to impose them on the subordinates (staff members). Schermerhorn, Hunt and Osborn (2000) collaborated with this view when they explained school-based leadership as a case of interpersonal influence that get individuals and/ or groups of the school community willingly doing what the head of the school wants to be done, in line with the achievement of the vision and mission of the school as an institution.

The modern conception of school-based leadership embraces tactics that would motivate staff to willingly contribute their individual quota to the achievement of the ultimate goal of the institution. On the same wave length, Sinha andParvinder (2002) contended that this conception of school-based leadership upholds rationale persuasion. Thus, reasoning with subordinates or staff members of the school to impress upon them to appreciate the rationale, for which they must perform well, without which the institutions will not be able to make its' vision and mission a reality.

\subsection{Theories of Organizational Management Underpinning the Conceptualizations of School-Based Leadership}

It emerged from the study that the traditional conception of school-based leadership is underpinned by the classical theory of organizational management, while the modern conception is underpinned by the human relation theory of organizational management. The classical theory of organizational management became popular during the industrial revolution era in the 1930's, and is still a major influential management theory on the economic rationale of institutions (Shafritze, Ott \& Jong, 2005). The classical theory embodies two distinct perspectives; scientific management which emphasizes on the scientific management of the individual worker, and task assigned to him/ her as a means of identifying the "one best way" to execute a task and administrative management which addresses issues regarding management of an entire organization (Lunenburg \& Ornstein, 2012). Shafritze et al., (2005) have observed that the classical theory of organizational management is hierarchical in nature regarding authority. According to Bonsu and Ampah-Mensah (as cited in Amarkyi et al., 2015), the classical thinkers of organizational management proposed the scientific analysis of job/ task and established standards to be attended to base on process and outputs, with little or no consideration for the human factor in management. In contributing to this theory, MacCallum as cited in (Onday, 2016) designed the first organizational chart and associated the top down approach of information flow with it.

The human relation approach to organizational management became popular in the 1940's and early 1950's, when it created the awareness to managers, the critical role played by workers or subordinates in the determination of the success or failure of an organization (Plano as cited in Indabawa \& Uba, 2014). Thehuman relation theory emphasizes on an ideal and perfect interaction between managers and subordinates at the work place, and motivation for workers, towards enhancing efficiency and increased productivity (Indabawa \& Uba, 2014).

Institutions all over the world, whether formal or informal once in existence have their operations underpinned by one or more theories of management. The traditional conception of school-based leadership is underpinned by the classical theory of organizational management. According to Bosu and Ampah-Mensah (as cited inAmakyi et al., 2015) in an attempt to seek for solution to the question "how could job be executed efficiently"? The classical thinkers of organizational management proposed scientific analysis of job/ task and established standards to be attended to,based on processes and outputs, with little or no consideration for the human factor in organizational management. The modern conception of school-based leadership is driven largely by the human relation approach to organizational management. This approach entreats heads of educational institutions to create cordial human relations at the work place through participatory decision-making, and the creation of opportunities for individual's growth and development Bosu and Ampah-Mensah (as cited inAmakyi et al., 2015).

Preponderantly, the traditional conception of school-based leadership is about the leader (head) exercising power or authority over subordinates (staff members) in getting task performed. Characteristic of the classical conception of school-based leadership is top down exercise of power and authority over staff members by the head, largely based on guidelines provided by higher authorities in getting work done at the school level. While the modern conception is based on motivation, cordial and friendly work environment, room for initiative and personal improvement on the part of staff members, and participatory decision-making among others. Also, the modern conception seeks to ensure respect and concern for staff members and recognizes them as a source of knowledge, creativity and integral component in the school environment.

It is evidently clear in the literature that both the traditional and modern conceptions of school-based leadership are geared towards goal accomplishment. Again, built in the two conceptions of school-based leadership espoused above, is the recognition that leadership is not an oasis in itself ,in the life of educational institution and others. Every leader in the school setting has followers (staff members), and the contributions of the staff members in the performance of the school as an institution, cannot be relegated unto the background.

As the traditional conception of school-based leadership is underpinned by the classical theory of organizational management, it is equally handicapped by the weaknesses of this theory. For example, the classical theory of 
organizational management is silent on the human factor, rather its emphasis task and structures. It has little or no consideration for staff members' feelings and aspiration as necessary factors. That when well treated, could blend well with task and structures to maximize output. On the other hand, the modern conception of school-based leadership is underpinned by the human relation theory of organizational management and therefore, the weaknesses of the human relation theory also affect this conception. For instance, at what point could the feelings and aspirations of the worker (in this case staff members) be said to be satisfied such that staff members could give off their best to maximize output. Therefore, juxtaposing the two conceptions to deduce a common conception out of the two could be the way forward.

Hence, in the context of this study school-based leadership would be explained as theputting of strategies in place, at the school level that make each member of the school community to feel needed, and to own the school regardless of his/ her membership status to enable them contribute their quota willingly towards addressing the day-to-day challenges that face the school as a unit, and also for them to appreciate and buy into policies structures made by the center (government) that makes the school as a unit to conform to the educational aspirations of the larger society. In the pursuit of this, school heads should try their possible best to ensure that situations do not arise where staff members may feel intimidated, victimized, relegated unto the background or neglected and hated among others. That notwithstanding, heads of schools should ensure that staff members have a sense of duty and respect for structures of the school to ensure sanity in the school environment. The strategies to help achieve this include; organizing regular staff meetings, occasionally delegating subordinates to represent the school at workshops and/ or seminars, making circular letters readily available to subordinates at the right time and sharing the concern of staff members among others.

\section{Conclusion}

The study discovered two schools of taught when it comes the understanding of the concept school-based leadership. These are the traditional and modern conceptions of school-based leadership. The traditional conception is characterized by bureaucratic, hierarchical and coercive principle among others, and underpinned by the classical theory of institutional management. While the human relation theory of organizational management is underpinnedby the modern conception which is characterized by collective decision-making and for that matter respect for individual views and suggestions, personal initiatives on the part of subordinates in getting work done or problems solved, motivation, concern for individual and institutional development, cordial and/ or friendly work environment and respect for each other among others.

\section{Implications for Practice}

This paper recommends that heads of schools be made to have a broader understanding of the concept schoolbased leadership that reflects both the traditional and modern conceptions to enable them to have effective leadership for the various schools. It should also be realized that leadership is dynamic process that every leader irrespective of the organization should factor both human relevant factors as well as strategic principles. In the school, heads should blend both human relation factors and scientific management approach.

\section{References}

i. Amakyi, M., Ampah-Mesnah, A., Bosu, R. S., \& Dare, A. (2015). The educational administrator: Leading and managing for better schools. Accra: Wrenco Publishers \&Printers.

ii. Andeson, T. D., Ford, R., \& Hamilton, M. (1998). Transforming leadership: Equipping yourself and coaching others to build leadership organization. London: St. Lucie Press.

iii. Beatriz, P., Deborah, N. \& Hunter, M. (2008). Improving school leadership: Policy and from: https:/ / www.oecd.org/ edu/ school/ 44374889.pdf

iv. Caldwell, B. J. (2005). School-based management. International Institute for Educational Planning. Retrieved from: http:// www.toolkit.ineesite.org/ resources/ineecms/ uploads/ 1373/Caldwell,_B. J._2005_S choolbased management.pdf

v. Conley, S. (1991). Restructuring schools: Educators adapt to a changing world. Eugene, OR: ERIC Clearinghouse on Educational Management.

vi. Danchi, N. N. (2014). Leadership styles and school climate in senior high schools in the central region of Ghana. Journal of Educational Management vol. 6 (117-129).

vii. Indabawa, S. L., \& Uba, Z. (2014). Human relation and behavioural science approach to motivation in selected businesses organization in Kano Metropolis Nigeria. European Journal of Business and Management. Vol. 6, No. 255,2014

viii. Lunenburg, F. C. \& Ornstein, A. C. (2012). Educational administration: Concepts and practices. Belmont, CA: Wadsworth, Cengage Learning.

ix. Jones, G. R., \& George, J. M. (2002). Essentials in managing organizational behaviour. Saddle River: Prentice-Hall.

x. Maxwell, J. C. (1999). The 21 st indispensable qualities of a leader: Becoming the person others will want to follow. Tennessee: Thomas Nelson Publishers.

xi. Nothouse, P. G. (2016). Leadership: Theory and practice. Thousand Oaks, CA: Sage Publications, Inc.

xii. Onday, O. (2016). Classical organizational theory: From generic management of Socrates to bureaucracy

Weber. International Journal of Business Management and Review. Vol. 4, No. 1, pp. 87-105.

xiii. Popovici, V. (2012). Similarities and differences between management and leadership. Annals-Economy Series, 2, 126-135.

xiv. Rothwell, J. D. (2002). Inthe company of others: An introduction to communication. New York McGraw Hill. 
xv. Schermerhon, J. R., Hunt, J. G., \& Osborn, R. N. (2000). Organizational behaviour). New York: John Wiley and Sons Inc.

xvi. Shafritz, J. M., Ott, J. S., \& Jang, Y. S. (2005). Classical of organizational Theory. Belmont, CA: Wadsworth.

xvii. Simonton, D. K. (1994). Greatness: Who makes history and why. New York: Guilford Press.

xviii. Sinha, J. B. P., \& Parvinder, G. (2002). Preferred leadership styles and influence tactics. Journal

of Management Studies, Vol. 2. No. 1, January 2002.

xix. Tandoh, V. C. (2011). Effect of leadership behaviour on employee's performance in Guinness Ghana Limited. The Institute of Distance Learning, Kwame Nkrumah University of Science and Technology, Kumasi, Ghana. Retrievedfrom:http:/ / ir.knust.edu.gh/ bitstream/ 123456789/ 4462/ 1/ VERONICA\%20CELATTIA\%20THESIS\%202 011.pdf

xx. Van Fleet, D. D., \& Peterson, T. O. (1988). Contemporary management. Boston: Houghton Mifflin. 